\title{
Correction to: In silico characterization of putative gene homologues involved in somatic embryogenesis suggests that some conifer species may lack $L E C 2$, one of the key regulators of initiation of the process
}

Sonali Sachin Ranade ${ }^{*}$ and Ulrika Egertsdotter

Correction to: BMC Genomics 22, 392 (2021)

https://doi.org/10.1186/s12864-021-07718-8

Following publication of the original article [1], it was reported that the image files for Figs. 3 and 4 were erroneously swapped. The correct Figs. 3 and 4 with their correct captions are given in this Correction article, and the original article has been updated.

Published online: 07 July 2021

\section{Reference}

1. Ranade SS, Egertsdotter U. In silico characterization of putative gene

homologues involved in somatic embryogenesis suggests that some

conifer species may lack $L E C 2$, one of the key regulators of initiation of the process. BMC Genomics. 2021;22:392 https://doi.org/10.1186/s12864-02107718-8.

The original article can be found online at https://doi.org/10.1186/s12864021-07718-8.

* Correspondence: Sonali.Ranade@slu.se

Department of Forest Genetics and Plant Physiology, Umeå Plant Science Center (UPSC), Swedish University of Agricultural Science (SLU), 90183

Umeå, Sweden

(c) The Author(s). 2021 Open Access This article is licensed under a Creative Commons Attribution 4.0 International License, which permits use, sharing, adaptation, distribution and reproduction in any medium or format, as long as you give appropriate credit to the original author(s) and the source, provide a link to the Creative Commons licence, and indicate if changes were made. The images or other third party material in this article are included in the article's Creative Commons. licence, unless indicated otherwise in a credit line to the material. If material is not included in the article's Creative Commons licence and your intended use is not permitted by statutory regulation or exceeds the permitted use, you will need to obtain permission directly from the copyright holder. To view a copy of this licence, visit http://creativecommons.org/licenses/by/4.0/. The Creative Commons Public Domain Dedication waiver (http://creativecommons.org/publicdomain/zero/1.0/) applies to the data made available in this article, unless otherwise stated in a credit line to the data. 


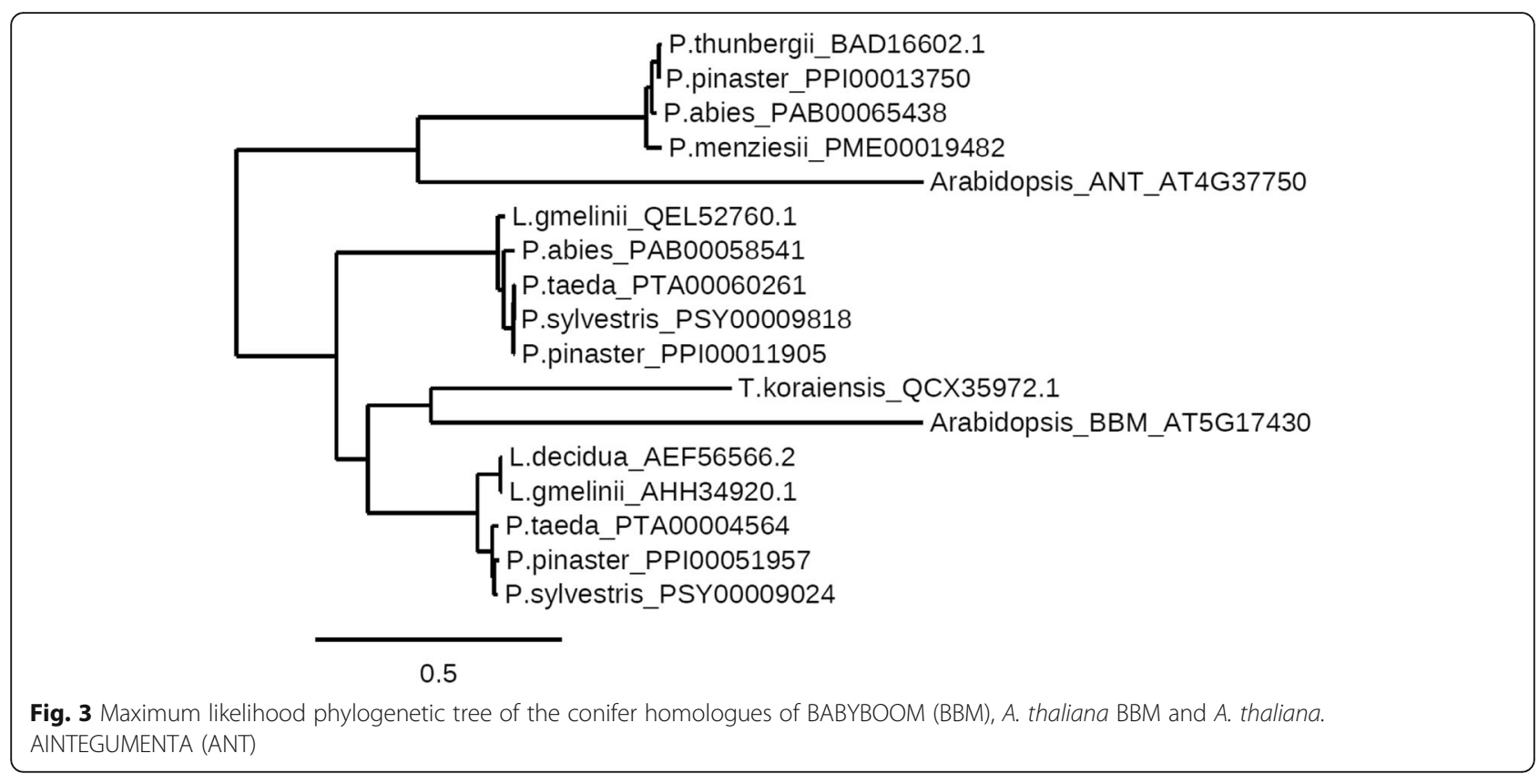




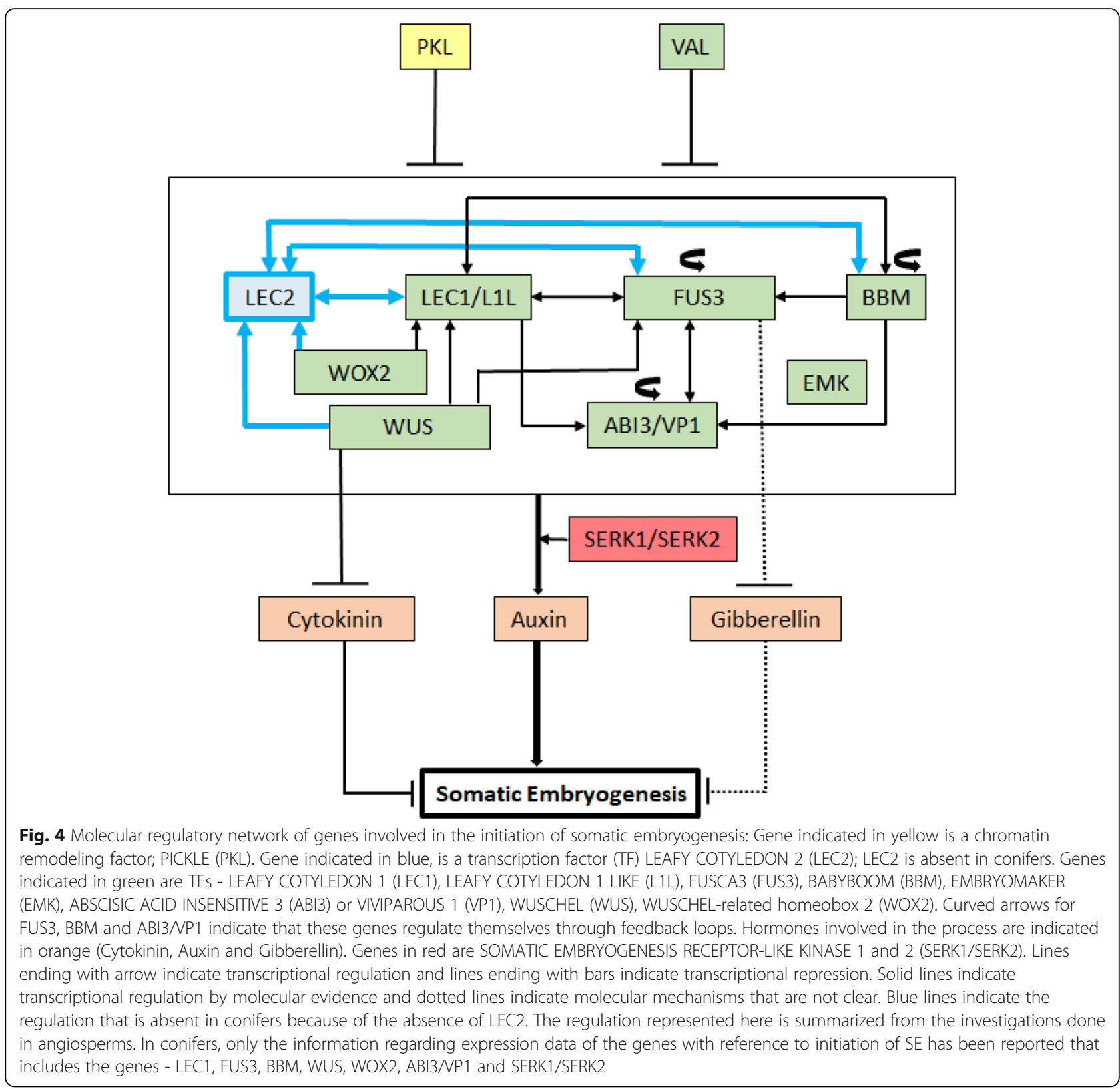

